\title{
Regulatory function of stress in the process of leukemia patients' recovery after bone marrow transplantation
}

\begin{abstract}
The theoretical rationale was the author's Functional Model of Health (FMH), where health is construed as a function of creative coping with stress. Participants in the study were 141 patients with blood cancer $(80$ men and 61 women) treated with bone marrow transplantation at the Hematology Clinic, Jagiellonian University Collegium Medicum. Besides a standardized interview the following instruments were used: STAI by Spielberger, CISS and CHIP by Endler and Parker, and SOC-29 by Antonovsky. Health status was operationalized using 10-point self-rating scales to assess the patients' perceived health and sense of calmness, while their objective health was rated by a medical expert hematologist. In the statistical analyses significant correlations were found between stress level and the patients'subjective health (-0.34, $p<0.001)$. The following variables predicted stress intensity: anxious personality (.585), distraction coping strategy (-.202), female sex (.201), and sense of meaningfulness (-.190). Subjective health predictors of leukemia patients are: objective health $(\beta=.413)$, level of stress $(\beta=-.285)$, by the patient's sense of meaningfulness $(\beta=.244)$ and focusing on negative emotions $(\beta=-.193)$. To promote patients' health moreover, their sense of meaningfulness in life and in being active should be supported and enhanced.
\end{abstract}

Key words: resources, health, coping, bone marrow transplantation, stress, illness

\section{Background}

Stress, inseparable from the contemporary man's life, is generally believed to negatively affect human health. This opinion is shared by classical researchers investigating stress problems, irrespective of how they construe stress: as the cause of illness, its effect, or as a relation/transaction between the two (Selye, 1977; Solomon, 1972; Lazarus \& Folkman, 1984).

In the last quarter of the $20^{\text {th }}$ century the literature dealt not so much with the nature and definitions of stress, but rather with behaviors of people in stressful situations (Łosiak, 2007; Heszen, 2013). The focus of research interest is there on ways of coping with stress, i.e. on strategies, styles, and the process of coping. Specificity of these constructs is defined: while strategies are closely related to a concrete situation, styles are considered to be relatively stable and corresponding to personality dispositions. As emphasized by researchers, the condition of compatibility between a person's strategy and their style of coping should be fulfilled, e.g. task-oriented coping style should be associated with a task-driven strategy (HeszenNiejodek, 1996; Miller \& Mangan, 1983; Wrześniewski, 2004). On the other hand, the process of coping is associated with temporal factors including its duration and course that may be phasic, at least according to some researchers (Kubler-Ross, 1972; Taylor, 1983).

Despite an increasing number of studies major problems concerning the essence of stress and coping have not been solved yet, e.g. the question unanswered so far - whether it is good to have one's own coping style? Attempts to elucidate this problem were presented in the author's monographs (Wrona-Polańska, 2003, 2011). Likewise, the years' long controversy about what is primary and what is secondary in the realm of stress - cognition or emotions - has never been definitely settled (Zajonc, Marphy \& Inglehart, 1989; Maruszewski, 2002). Daily life observations, the author's clinical experiences in work with leukemia patients as well as her research indicate an important role of stress in human life, protecting people from loss of health or even life (Wrona-Polańska, 1984, 1985, 1989, 1991, 2007, 2011).

\footnotetext{
* KEN Pedagogical University of Krakow 
The crucial problem can be reduced to the question: what is the function of stress in health/illness?

\section{Stress and health/illness}

According to Antoni Kępiński (1977), anxiety (equivalent to stress in health psychology) is, besides pain, another signal of threat resulting from disturbed balance in information metabolism. Anxiety is an indicator of threat to cognitive structures, i.e. to health in the psychological dimension. Anxiety thus defined fulfills a regulatory role.

The aim of this study is to establish the function of stress in the context of health, leaving aside its negative effects such as occupational burnout or various diseases. The problems of stress will be investigated from the salutogenic perspective assuming that due to the individual's personal resources stress can have a positive, protective function in a stressful interaction (Heszen \& Sęk, 2007).

The inspiration for the author's striving to explain psychological mechanisms and determinants of health came from her clinical practice and her own research involving patients with leukemia (Wrona-Polańska, 2003), a condition regarded in the early 1980s as incurable, with the average duration of survival in acute leukemia ranging from 4 months to 1 year (Blicharski, Kwiatkowski, Pochopień \& Wolska 1983).

In the author's research on health a baseline assumption was made that there is a relationship between stress and health. The rationale behind her studies was the cognitive-transactional approach by Lazarus and Folkman (1984) proposing that the level of experienced stress is determined by the individual's subjective appraisal of their relationship with the environment where demands exceed their capabilities and pose a threat to their wellbeing. There is a clear association between stress and health. This conception of stress is supplemented by the theory of conservation of resources, (COR) by Hobfoll (1989) holding that the source of stress consists in any apparent or real loss of resources or in a lack of reasonable gain after resource investment. Resources are construed there as properties that fulfill a positive protecting role in the stressful interaction, i.e. buffer negative effects of stress (Heszen \& Sęk, 2007; Wrona-Polańska, 2003).

In the salutogenic concept by Antonovsky (1995) health is defined as a process of maintaining balance between environmental demands (stressors) and the individual's possibilities (resources).

The main research hypothesis was that although in classical studies stress is considered as a risk factor for many diseases (Baltrush, 1975; Solomon \& Amkraut, 1972), the nature of stress is not unambiguously negative - stress may have a positive, health-promoting function owing to mobilization of the individual's personal resources that aid creative coping and induce positive emotions.

Coping with stress can be conducive to health provided that it leads to successful problem solving in a way permitting to attain the individual's goal. However, this is not always and not under any circumstances possible.
Traditional methods of leukemia treatment have limited effectiveness - these patients can regain health only owing to modern treatment methods such as bone marrow or stem cells transplantation.

The patient faced in this situation with new problems is required to engage in creative activity and co-operate with the therapeutic team in striving for recovery. In accordance with the theory of Creative Problem Solving (CPS) (Nęcka, 1994), this process necessitates continuous informational powering, i.e. a constant supply of information allowing to appraise the problem, as well as energetic powering, i.e. a supply of energy provided by positive emotions as stimulators of engaging in healthoriented activities.

Creative Problem Solving is a process of constant adjustment of rational and irrational strategies to cognitive appraisal of the situation, finally leading to a realistic and/or irrational solution of the problem using a positive revaluation strategy conducive to regulation of emotions. The patients' creative coping with stress implies that in the process of appraising their condition from the perspective of their own capabilities/resources they perceive it as a challenge. This includes not only their decision to undergo bone marrow transplantation on attaining a complete or satisfactory remission, but also their engagement in recovery-oriented efforts. However, the patients' creative coping is not synonymous with efficacy of their activity or with a successful treatment outcome, since it is still difficult to achieve full recovery in leukemia and other blood cancers - the average survival rate after bone marrow transplantation is only about $50 \%$. Coping efficacy depends on the patient's individual, personal resources, particularly on intrapsychic processes. The latter include secondary control that may enable the patient to change their self-appraisal into a more positive one allowing to undertake this difficult challenge (Wrona-Polańska, 2003, 2011).

The present author's Functional Model of Health (FMH) developed on the grounds of the theories outlined above was empirically verified in a study involving 299 healthy volunteers. Multiple determinants and psychological mechanisms of health were found in the study (Wrona-Polańska, 2003, p. 210).

According to the FMH, an important role in the maintenance of health (or a dynamic balance both within the organism and in the man-environment relationship), is fulfilled by a pro-health personality characterized by a number of personal cognitive resources - a strong sense of coherence (SOC), positive self-appraisal, as well as a sense of control and self-control in coping with external and internal demands. Pro-health personality influences health via competence-related, affective, and stress-related pathways. A significant indicator of health/illness is the tension-and-stress pathway that has no direct connections with the competence path. Thus, coping processes are not directly triggered by the experienced stress - the stressful situation has to be appraised in terms of personal resources available and it is only such stress appraisal that activates the process of coping. As indicated by the results of path 
analysis (shown in brackets), the tension/stress-related pathway $(-.31)$ is counterbalanced by the competence pathway of creative coping (.14) and the pathway of positive emotions (.14). Pro-health personality to the same extent supports effective coping strategies (.63) as it prevents stress (-.63). In other words, the individual's strong resources conducive to problem solving reduce the level of experienced stress, and in consequence secure the maintenance of balance in the man-environment system, i.e. the maintenance of health.

The Functional Model of Health has corroborated the Lazarus and Folkman theory and the importance of cognitive appraisal for the coping process activation. The research findings have also confirmed the hypothesis that health is a function of creative coping with stress namely, a positive role of stress due to mobilization of the individual's personal resources has been shown.

\section{Medical and psychological aspects of blood cancers and their treatment}

Blood cancers, particularly leukemias, due to their specificity and systemic character can be classified among the most dangerous diseases with poor prognosis. At the moment of diagnosis the neoplastic process is already spread all over the organism via the hematopoietic system. Thus, these conditions should be diagnosed as soon as possible. Besides, they require specialist, intense and diversified treatment (Janicki, 2001, Skotnicki \& Nowak, 1989, Wit, Szczepański \& Dawidowska, 2009), including both biomedical and psychosocial factors (Aleksandrowicz, Ćwiklicka \& Płużek, 1971, Akabo et al., 2003, Jabłoński, 2004, Lebiedowicz \& Skotnicki, 2005, Molassiotis, 1997, Schultz-Kindermann, Hennings, Ramm, Zander \& Hasenbring, 2002).

The author's clinical experience and her own research indicated a significant role of anxiety experienced by the patient and of repressive defense mechanisms in coping with anxiety in the process of adaptation to leukemia (Wrona-Polańska, 1985, 1989). Moreover, the importance of the patient's recovery-oriented activity undertaken in this extremely stressful situation was highlighted. The source of positive energy in the process of coping with illness turned out to involve positive emotions resulting from the patient's self-acceptance in the sick role, mobilizing him to co-operation with the therapeutic team and to healthpromoting activities (Wrona-Polańska, 1984, 1991).

It is only since 1998 that a possibility of regaining health has been available to leukemia patients at the Professor Julian Aleksandrowicz Hematology Clinic, Collegium Medicum, Jagiellonian University, where about 1000 bone marrow and hematopoietic stem cells transplantations were performed over 17 years in cases of different hematopoietic system malignancies (The Hematology Clinic Team, 2015). This level of treatment efficacy is comparable to the greatest achievements worldwide. Nevertheless, the survival rate is only about $50 \%$, while the other $50 \%$ die at various stages of therapy. The mortality depends on a number of factors, including the patient's age, stage of disease, and transplantation type (Hołowiecki, 2006).

Risks involved in the bone marrow transplantation were found to include the disease recurrence and infectious complications as most frequent causes of failure in this type of treatment (Styczyński, Dębski, Krenska, Czyżewski \& Irga, 2013).

In their review of the literature Jakitowicz \& Piekarska (2014) highlighted the bone marrow transplantation process complexity from the psychological perspective. Long-term treatment necessitating the patients' isolation leads to their fear, depression and anxiety that can be counterbalanced by social support. In each individual case these factors determine the patient's condition after bone marrow transplantation.

Most studies in this field are concerned with stress experienced by the patient after bone marrow transplant, the accompanying symptoms, and health-related quality of life. In a psychological follow-up study of 236 patients at an average of 3 to 4 years after bone marrow transplantation in $43 \%$ of the participants increased levels of stress were found (Rusiewicz \& Duhamel, 2008), in addition to feelings of loneliness, memory impairments, and existential problems. A considerable number of studies deal also with social support.

An interesting research project on the relationship between partner social support and the level of distress in patients after stem cell transplantation (Rini, Redd \& Austin, 2011) revealed that the effectiveness of social support was more important for patient distress reduction than was the amount of support provided.

Modern methods of blood cancer treatment, i.e. bone marrow transplantation (BMT) and hemopoietic stem cells transplantation (SCT) giving the patient "a second chance for life" have contributed to altering the psychological stereotype of leukemia seen as a lethal risk into that of a curable condition (Wrona-Polańska, 2011), becoming a challenge and inspiration for research on psychological mechanisms underpinning recovery in blood cancer patients who receive this type of treatment.

The aim of the present study was to show the function of stress in the context of health/disease within the framework of the Functional Model of Health (FMH) (Wrona-Polańska, 2003), where health is conceptualized as a function of creative coping with stress, (with function understood in the mathematical sense as a relationship between two variables where a change in the value of one variable results in a change in the value of the other). The operationalized paradigm of the author's wide-ranging research (Wrona-Polańska, 2011, p. 157) plotted in Fig. 1 shows the direction of relationships indicating that health of patients after bone marrow transplantation depends on their stress level, styles and strategies of coping, as well as on their individual, personal resources.

The main research problem of the study consists in the question: What is the level of stress experienced by the patients and what does it depend on? The patient's stress level was assumed, firstly, to be an indicator of health/ illness, and secondly, to depend on the ways of coping used by the patient and on his individual, personal resources. 
Figure 1. Model of health determinants in leukemia patients (Wrona-Polańska, 2011, p. 157)

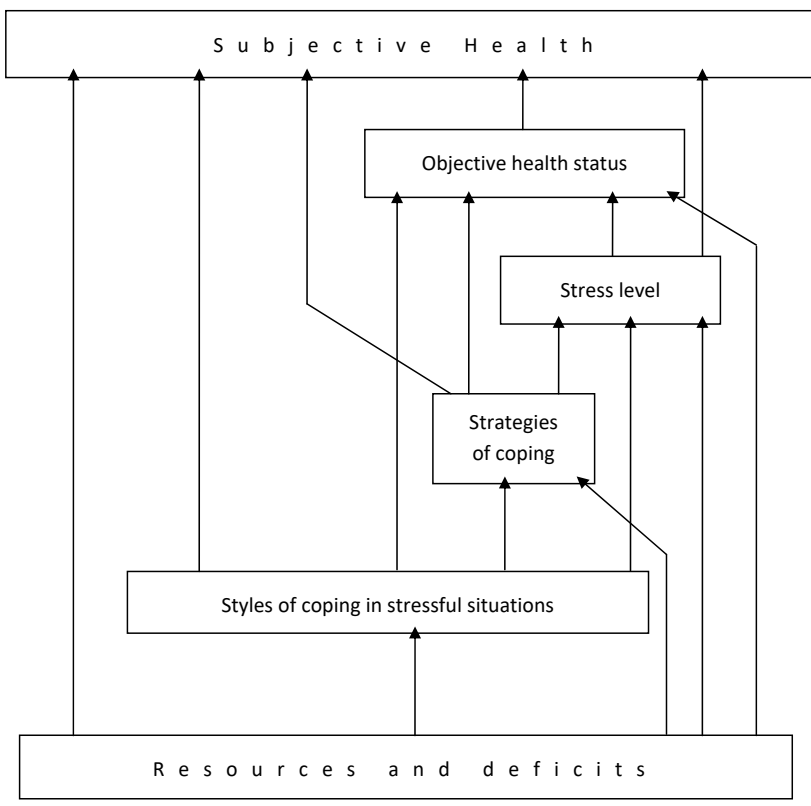

In accordance with the assumed model of relationships the following research hypotheses were posed.

1. Health status of leukemia patients after bone marrow transplantation is associated with: their experienced stress level, styles and strategies of coping with stress and the patient's personal resources.

2. Patients' health subjective depends on the level of stress: the higher stress, the lower subjective health.

3. Stress predictors are: strategies of coping and personal resources/deficits.

4. Subjective health predictors of leukemia patients are: objective health and level of stress.

The hypotheses posed determined the direction of data analysis.

\section{Methods, research instruments, and study sample characteristics}

The choice of assessment tools was influenced by the Functional Model of Health on the one hand, and on the other by capability of the patients presenting with considerable weakness and fatigability after bone marrow transplantation (BMT).

Clinical interview and observation during the assessment were the main techniques used to describe the patient's lifestyle after the BMT, including their overall condition, experienced emotions, functioning in the family and at work, ways of coping with problems, sources of support, and generally, their post-transplant quality of life.

Three groups of variables were measured: health, stress, and resources.

The first variable, subjective health, was operationalized using two indicators: self-rated health (i.e. feeling healthy) and a sense of calmness (i.e. feeling calm), assessed by the patient on 10-point scales (from 1-sick to 10-healthy, and from 1 -anxious to 10 -calm). The patients were asked to justify their ratings. The "subjective health" variable was construed as the mean of scores on these two rating scales measuring self-perceived health and sense of calmness.

The patients' objective health status was assessed on a 10 -point rating scale by the same medical experthematologist.

Stress was assessed using the X1 version of the State-Trait Anxiety Inventory (STAI) questionnaire by Spielberger in the Polish adaptation by Sosnowski and Wrześniewski (1983). Coping styles were measured with the Coping Inventory for Stressful Situations (CISS) by Endler and Parker (1994); the scale covers three styles: task-, emotion-, and avoidance-oriented (via distraction and seeking social contacts). The highest Cronbach alpha reliability coefficient $(0.87)$ was obtained for task-oriented coping. Strategies of coping with illness were assessed using the Coping with Health Injuries and Problems (CHIP) scale by Endler and Parker in the Polish adaptation by Wrześniewski (1996) - the instrument measures 4 strategies: distraction or diverting attention from illness, palliative - stimulation reducing, instrumental coping, and focusing on negative emotions. Data concerning strategies were submitted to qualitative analysis.

Anxious personality was evaluated using the STAI X2, while the patients' sense of coherence by means of the Orientation to Life (SOC-29) scale by Antonovsky (1995). The Cronbach alpha coefficient for the SOC scale was 0.88 , and for the meaningfulness subscale 0.80 .

Since the questionnaire techniques listed above are generally well-known and widely used in psychological research, their detailed description does not seem necessary here.

The study sample consisted of leukemia patients treated with bone marrow transplantation at the Hematology Clinic, Jagiellonian University, Collegium Medicum. They were assessed during a post-transplant check-up at the Clinic. Data obtained from 141 patients were analyzed. The participants were 80 men and 61 women, at the mean age of 39.7 years $(\mathrm{SD}=12.7)$, the majority were in the 20-40 age range, had a secondary education, and were assessed about a year after the surgery.

In statistical analyses the STATISTCA packet was used, and $p<0.05$ level was assumed to indicate significant regularities.

\section{Results}

\section{Stress level and the patients' ways of coping with leukemia and bone marrow transplantation}

The level of stress experienced by the patients was average (see Table 1) and gender-related, being significantly higher in women $(\mathrm{M}=41.9, \mathrm{SD}=11.1)$ than in men $(\mathrm{M}=37.6, \mathrm{SD}=8.7, t=2.567, d f=139$, $p<.011)$. Task-oriented coping style and instrumental coping strategies predominated in the sample, as well as avoidance-oriented style and distraction strategies to divert attention from illness through seeking persons and things evoking positive emotions. Emotion-oriented coping style oscillated around the average level, with 
Table 1. Variables describing health, coping styles \& strategies and resources - basic descriptive statistics

\begin{tabular}{|c|c|c|c|c|c|}
\hline Variables & Number of patients & Mean score & $S D$ & Min. & Max. \\
\hline \multicolumn{6}{|l|}{ Health } \\
\hline Self-rated health & 141 & 6.69 & 2.51 & 1 & 10 \\
\hline Sense of calmness & 141 & 7.04 & 2.03 & 1 & 10 \\
\hline Objective health status & 140 & 7.70 & 2.09 & 2 & 10 \\
\hline Stress level & 141 & 39.43 & 10.00 & 21 & 69 \\
\hline \multicolumn{6}{|l|}{ Coping style } \\
\hline Task-oriented & 141 & 56.40 & 8.40 & 23 & 73 \\
\hline Emotion-oriented & 141 & 39.57 & 9.88 & 21 & 66 \\
\hline Avoidance-oriented & 141 & 46.37 & 8.71 & 21 & 69 \\
\hline Distraction & 141 & 20.52 & 5.07 & 8 & 33 \\
\hline Seeking social contacts & 141 & 17.30 & 4.22 & 5 & 26 \\
\hline \multicolumn{6}{|l|}{ Strategies of coping with illness } \\
\hline Diverting attention from illness & 140 & 26.40 & 4.53 & 11 & 35 \\
\hline Reducing stimulation & 140 & 19.51 & 3.87 & 9 & 29 \\
\hline Instrumental coping & 140 & 31.39 & 5.23 & 15 & 40 \\
\hline Focusing on negative emotions & 140 & 25.84 & 6.33 & 13 & 40 \\
\hline Sense of coherence (global) & 111 & 140.84 & 22.87 & 66 & 197 \\
\hline Comprehensibility & 111 & 45,71 & 10,39 & 19 & 71 \\
\hline Manageability & 111 & 51.11 & 8.75 & 22 & 70 \\
\hline Meaningfulness & 111 & 43.94 & 7.23 & 17 & 56 \\
\hline Anxious personality & 141 & 41.23 & 9.14 & 23 & 70 \\
\hline
\end{tabular}

Table 2. Pearson's r coefficients of correlation between stress levels, strategies and styles of coping with illness and resources/deficits

\begin{tabular}{|c|c|c|c|c|c|}
\hline Variables & Stress level & $\begin{array}{l}\text { Diverting attention } \\
\text { from illness }\end{array}$ & $\begin{array}{c}\text { Reducing } \\
\text { stimulation }\end{array}$ & $\begin{array}{l}\text { Instrumental } \\
\text { coping }\end{array}$ & $\begin{array}{c}\text { Focusing on } \\
\text { negative emotions }\end{array}$ \\
\hline \multicolumn{6}{|l|}{ Coping styles } \\
\hline Task-oriented & $-.29 * * *$ & $.39 * * *$ & .15 & $.32 * * *$ & -.02 \\
\hline Emotion-oriented & $.51 * * *$ & -.14 & $.22 * *$ & .14 & $.63 * * *$ \\
\hline Avoidance-oriented & .05 & $.39 * * *$ & .10 & $.24 * *$ & .15 \\
\hline Distraction & .13 & $.22 * *$ & $.17 *$ & .14 & .12 \\
\hline Seeking social contacts & $-.21 *$ & $.50 * * *$ & -.01 & $.25 * *$ & -.07 \\
\hline \multicolumn{6}{|l|}{ Resources/deficits } \\
\hline Meaningfulness & $-.48 * * *$ & $.38 * * *$ & -.08 & $.27 * *$ & $-.31 * * *$ \\
\hline Anxious personality & $.76 * * *$ & $-.28 * * *$ & $.21 *$ & .02 & $.56 * * *$ \\
\hline
\end{tabular}

Significant at: $* p \leq .05 ; \quad * * p \leq .01 ; \quad * * * p \leq .001$ 
prevailing strategy of focusing on negative affectivity. The patients had a strong sense of coherence, particularly of manageability and meaningfulness leading to their belief about effectiveness and purposefulness of activities aimed at recovery. Moreover, their average scores on the anxious personality measure (see Table 1) were conducive to health maintenance at a satisfactory level.

Further analyses using Pearson's linear correlation were aimed to establish relationships between stress levels, strategies and styles of coping with stress, and personal resources (see Table 2).

Statistically significant positive correlations of experienced stress level were found with emotion-oriented style (.51) and the strategy of focusing on negative emotions (.63), while negative - with task-oriented coping style (-.29) and avoidance coping through seeking social contacts $(-.21)$. Strong positive relationships of distraction strategy were found with two coping styles: task- (.39) and avoidance-oriented (.39), particularly through seeking social contacts (.50). Instrumental coping strategy was significantly positively associated with task-oriented (.32) and avoidance-oriented (.24) styles, also via seeking social contacts (.25). Strong negative correlations of stress were noted with the patient's sense of meaningfulness (-.48), and positive - with anxious personality (.76). Pearson's $r$ correlation coefficients presented in Table 2 confirmed hypothesis 1 holding that the level of stress is strongly related to strategies and styles of coping and the patient's resources/deficits; the relationships were statistically significant at $p<.001$.

The findings suggest that the intensity of experienced stress, at least in some patients, is determined not only by a strong personality-related predisposition to anxiety, but also by strategies that predominate in their coping repertoire and are consistent with their coping style - namely, focusing on negative emotions, reducing stimulation, as well as not engaging in any emotionsuppressing activities.

\section{Stress and health}

The leukemia patients after transplantation (Table 1) scored high on their self-rated health and had a strong sense of calmness.

Their high ratings of perceived health and sense of calmness (given in brackets) are consistent with such responses as: I feel just fine, I am working, etc. (10), The worst is over, I am healthy and enjoying my life (9).

Few patients who rated their health low expressed their feeling ill in such responses as: I suffer from leukemia (1), I think my disease is incurable (3).

A strong sense of calmness is evidenced by such narratives as: I am always trying to keep calm (10); I am calm, because everything is OK so far (9).

Rather few patients expressed their low sense of calmness (or anxiety feelings) in such responses as: I see bacteria and viruses everywhere, I keep washing my hands and almost never leave my room, as I am afraid I might catch something infectious (1).
The patients' objective health status as assessed by the hematologist was above-average and significantly higher than their self-rated health $(p<.001)$ (Table 3$)$.

Table 3. Difference between patients' self-rated health and their health status assessed by medical expert

\begin{tabular}{|c|c|c|c|}
\hline Variable & $\begin{array}{l}\text { Mean } \\
\text { score }\end{array}$ & $S D$ & $\begin{array}{c}\text { Paired } \\
\text { samples } \\
\text { t-test }\end{array}$ \\
\hline Self-rated health & 6.69 & 2.52 & \multirow{3}{*}{$\begin{array}{l}t=-4.590 \\
d f=139 \\
p<.001\end{array}$} \\
\hline Health status assessed by doctor & 7.70 & 2.09 & \\
\hline $\begin{array}{l}\text { Difference between the } \\
\text { patient's and doctor's ratings }\end{array}$ & -1.01 & 2.60 & \\
\hline
\end{tabular}

The aim of further analyses was to verify hypothesis 2 concerning relationships between stress and health. Linear correlation analysis has shown interesting associations of stress level with indicators of the patients' self-rated health and sense of calmness, as well as with their objective health status (Table 4).

Table 4. Pearson's r coefficients of correlation of stress level with the patients' subjective health indicators and their objective health

\begin{tabular}{cccc}
\hline Variables & $\begin{array}{c}\text { Self-rated } \\
\text { health }\end{array}$ & $\begin{array}{c}\text { Sense of } \\
\text { calmness }\end{array}$ & $\begin{array}{c}\text { Objective } \\
\text { health }\end{array}$ \\
\hline
\end{tabular}

Stress

\begin{tabular}{llll}
\hline Stress level $-.34 * * *$ & $-.58 * * *$ & -.05 \\
\hline Significant at $* p \leq .05 ; \quad * * p<01 ; \quad * * * p<.001$ &
\end{tabular}

Significant at: * $p \leq .05 ; \quad * * p \leq .01 ; \quad * * * p \leq .001$.

Pearson's $r$ coefficients of correlation reveal strong negative relationships of the patients' experienced stress levels and their subjective health indicators, i.e. feeling healthy (-.34) and feeling calm (-.58), both statistically significant at $p<.001$. This means that the higher is the patients' experienced stress, the lower their perceived health and sense of calmness, and vice versa. The strength of this association between stress and health may indicate a regulatory character of stress in the context of health, mobilizing patients to activity on behalf of their health.

No significant association between experienced stress and the patients' objective health may suggest that medical indicators used in the health assessment are unrelated to stress.

\section{Predictors of stress}

Multiple regression analysis used to determine stress predictors in the sample under study yielded the model of stress presented in Table 5. 
Table 5. Model explaining stress level

\begin{tabular}{|c|c|c|c|c|c|c|}
\hline \multirow{2}{*}{$\begin{array}{c}\text { Explained variable } \\
\qquad \mathbf{R} \text { and } \mathbf{R}^{2}\end{array}$} & \multirow[t]{2}{*}{ Effect } & \multicolumn{2}{|c|}{$\begin{array}{c}\text { Regression equation } \\
\text { parameter }\end{array}$} & \multicolumn{2}{|c|}{$\begin{array}{l}\text { Regression coefficient } \\
\text { significance test }\end{array}$} & \multirow[t]{2}{*}{$\beta$} \\
\hline & & Value & Standard error & $t$ & $p$ & \\
\hline \multirow{2}{*}{ Stress level } & Free term & 37.33636 & 7.63036 & & & \\
\hline & Anxious personality & .62259 & .08200 & 7.593 & .000 & .585 \\
\hline $\mathrm{R}=.809$ & Diverting attention from illness & -.45382 & .16626 & -2.730 & .008 & -.202 \\
\hline \multirow{2}{*}{$\begin{array}{l}\mathrm{R}^{2}=65.4 \% \\
\text { corrected } \mathrm{R}^{2}=63.6 \%\end{array}$} & Sex $(1-$ women. $0-$ men $)$ & 4.54262 & 1.58562 & 2.865 & .005 & .201 \\
\hline & Meaningfulness & -.27441 & .11468 & -2.393 & .019 & -.190 \\
\hline
\end{tabular}

The model of stress as the explained variable shows that the source of stress includes both anxious personality $(\beta=.585)$ and female sex $(\beta=.201)$, as women more often experience intense stress and are characterized by higher levels of personality-related anxiety. Stress is counteracted by the strategy of distraction, i.e. denying/repressing stress $(\beta=-.202)$, and by the patient's sense of meaningfulness $(\beta=-.190)$, or the affective-motivational constituent of their sense of coherence that is conducive to their perceiving illness as a challenge and motivating them to recoveryaimed activities after bone marrow transplantation.

The multiple determination coefficient indicates that $64 \%$ of variance in the stress variable is explained by a joint effect of the proposed group of independent variables. The experience of stress, more frequent in women, is not necessarily threatening to health due to distraction strategy - diverting attention from illness through defensive denial or repression of negative emotions, when accompanied by a positive orientation to life and by finding meaning in life becomes a source of positive, health-promoting emotions, which confirms positive consequences of stress and its regulatory function.

Multiple regression analysis used to determine subjective health predictors in the sample under study yielded the model of health presented in Table 6 .

Subjective health predictors of leukemia patients are: objective health $(\beta=.413)$, level of stress $(\beta=-.285)$, by the patient's sense of meaningfulness $(\beta=.244)$ and focusing on negative emotions $(\beta=-.193)$. Subjective health are promoting objective health and sense of meaningfulness that is motivating them to recovery-aimed activities after bone marrow transplantation.

The multiple determination coefficient indicates that $48 \%$ of variance in the subjective health variable is explained by a joint effect of the proposed group of independent variables.

\section{Discussion}

The aim of the study was to investigate the function of stress in the process of leukemia patients' recovery after bone marrow transplantation.

As the theoretical rationale of the study the present author's Functional Model of Health (FMH) was assumed, where health is regarded as a function of creative coping with stress (Wrona-Polańska, 2003, p. 210). According to the FMH, the level of experienced stress and ways of coping are important indicators of health, mediating between health and pro-health personality, or the individual's personal resources.

Data obtained from 141 patients with blood cancers, mostly acute leukemia, treated at the Hematology Clinic, Collegium Medicum, Jagiellonian University, were analyzed yielding the following results.

The patients were characterized by moderate levels of experienced stress, statistically significantly higher in women than in men, as well as by marked emotion-oriented coping style together with the corresponding strategy of

Table 6. Model explaining subjective health

\begin{tabular}{|c|c|c|c|c|c|c|}
\hline \multirow{2}{*}{$\begin{array}{c}\text { Explained variable } \\
\qquad \mathbf{R} \text { and } \mathbf{R}^{2}\end{array}$} & \multirow{2}{*}{ Effect } & \multicolumn{2}{|c|}{$\begin{array}{c}\text { Regression equation } \\
\text { parametr }\end{array}$} & \multicolumn{2}{|c|}{$\begin{array}{c}\text { Regression coefficient } \\
\text { significance }\end{array}$} & \multirow[t]{2}{*}{$\beta$} \\
\hline & & Value & Standard error & $t$ & $p$ & \\
\hline \multirow{2}{*}{ Subjective health } & Free term & 3.77986 & 1.93671 & & & \\
\hline & Stress level & -.05860 & .02126 & -2.757 & .007 & -285 \\
\hline \multirow[t]{2}{*}{$\mathrm{R}=, 712$} & Objective health status & .43479 & .08617 & 5.046 & .000 & .413 \\
\hline & Meaningfulness & .07245 & .02809 & 2.579 & .012 & .244 \\
\hline corrected $\mathrm{R}^{2}=48,1 \%$ & Focusing on negative emotions & -.06764 & .03301 & -2.049 & .044 & -193 \\
\hline
\end{tabular}


focusing on negative emotions. The resulting accumulation of negative affectivity may be threatening not only to health, but even to life of patients after bone marrow transplantation.

The patients' task-oriented style and the corresponding strategy of instrumental coping are conducive to their engaging in activities aimed at recovery. A positive defensive function is fulfilled by the strategy of diverting attention from illness and by the corresponding avoidance coping through seeking support in the family and friends, as well as through pursuing activities that foster denial or repression of anxiety, including interest in music, arts, and nature.

Correlation analyses revealed strong, negative associations between stress and the patients' subjective health, statistically significant at $p<.001$, and no relationship between stress and their objective health status assessed using medical indicators. The relatively high level of objective health rated by the medical experthematologist as compared to the patients' self-rated health may be indicative of effectiveness of this treatment method enabling survival of about $50 \%$ of patients with blood cancers. However, their subjective perception, or feeling healthy, depends on their individual resources and on engaging in health-promoting activities.

Stepwise regression analysis has indicated that stress is strongly predicted by anxious personality as a stable disposition, moderate in the study participants, but enhanced by emotion-focused coping strategy. A defensive function protecting against stress is fulfilled both by the strategy of diverting attention from illness and by the meaningfulness component of the sense of coherence, i.e. a belief that life is meaningful and therefore it is worthwhile to engage in activities aimed to maintain life and regain health after transplantation.

In accordance with the Functional Model of Health, subjective health is a function of creative coping with stress appropriately to situation appraisal with regard to one's capabilities. Creative coping is not tantamount to effective coping, as it would denote real-life problem resolution (i.e. successful treatment outcomes with no exceptions). In the case of bone marrow transplantation patients this is not feasible not only for the patient, but also for the doctor or medicine in general. However, creative coping denotes also effective coping in another sense: each patient's individual resources allow not only to change their situation appraisal into a more positive one, but also lead to a more positive self-appraisal regarding their powers of coping with illness.

A question arises whether survival is possible only for patients who experience moderate stress levels, have health-promoting personality dispositions, positive attitudes towards life, and who cooperate with the therapeutic team in recovery-aimed efforts - in contradistinction to those with high experienced stress levels and anxious personality. Clinical observations and published research findings suggest that about a half of patients treated with the modern method of bone marrow transplantation survive, getting a second chance for life, while the other half die at various stages of treatment (Hołowiecki, 2006). This is related to a number of factors such as the disease duration and stage, the patient's age and positive attitude, etc.

In the light of the literature indicating immunosuppressive effects of stress (Solomon, 1985, 1990) it can be supposed that patients who have regained their objective health due to bone marrow or stem cells transplantation are persons characterized by personality-determined moderate levels of anxiety supported by the strategy of diverting attention from illness, i.e. denying or repressing anxiety through contacts with music and arts, as well as by seeking support from their family and friends. The fact that subjective health assessments made by patients after BMT are statistically significantly lower than these of their objective health status may result from their longterm, multi-stage invasive polychemotherapy frequently leading to their uncertainty and disbelief in possibility of full recovery and health restoration.

Research findings have shown that restoration of objective health due to bone marrow transplantation is just a beginning of the way to regaining subjective health, i.e. to feeling healthy. As follows from the literature (Susułowska, 1989) and the author's research (Wrona-Polańska, 2011, Wrona-Polańska, Skotnicki \& Piątkowska-Jakubas, 2013), subjective health has a higher regulatory power for behavior modification than objective health, therefore we should strive to help the patients regain their self-perceived health by encouraging their health-promoting activities and emotional regulation.

Strong inversely proportional relationships between stress and self-perceived health have shown the regulatory function of stress as an informational indicator that signals a discrepancy or disturbed equilibrium between demands (external or internal), i.e. stressors, and the individual's capabilities or resources allowing to regain the dynamic equilibrium or health through their enhancement. The higher is stress experienced by patients, the lower is their subjective health that leads them to undertake activities on behalf of health restoration and maintenance after transplantation.

The author's research has empirically confirmed that stress fulfills a positive regulatory role, provided that the individual is able to creatively cope with stress adjusting his strategies to the situation appraisal from the perspective of his own personal resources to regulate experienced stress intensity: while high levels of stress are a signal that health is threatened, the optimal level informs about good health. The presented research findings corroborate the positive informational function of stress in the context of health. Stress is an indicator of the individual's disturbed internal and/or external balance, while health is an indicator of not only a dynamic internal balance, but also of equilibrium in the man-world system. A practical implication follows that the individual can regain subjective health and good quality of life by strengthening his personal resources, and that health/illness is determined not only by external conditions.

In the Functional Model of Health (Wrona-Polańska, 2003) convergence of stress definitions proposed, respectively, by Lazarus and Hobfoll can be clearly seen. Stress level depends on the level of resources (Hobfoll, 
1989) since they decide about the patient's cognitive appraisal of the situation, about evoked emotions, and about creative coping with stress, therefore, in consequence - about his health level (Lazarus \& Folkman, 1984, Lazarus, 1999).

In order to regain subjective health creative coping with stress is necessary, using one's personal resources, employing rational and irrational strategies to engage in activities aimed at health restoration and maintenance. This is based on the belief that recovery is possible, but requires great effort. Creative coping with stress is different in each particular case since it originates from the specificity of individually defined meaning of life. A sense of meaningfulness of life is regarded by Obuchowski (1966) as the most important need. Creative coping requires then a personal belief that one knows "who and what makes life worth living". Therefore, stress fulfills an important regulatory role, as a signal of threat warning the patient about possible loss of health and life.

High stress may decrease or increase the patient's immunological sensitivity, in consequence involving the risk of transplant rejection. It is the stress level that serves as the indicator predicting transplant acceptance or rejection. This signal should be recognized and appropriately interpreted by the psychologist who should initiate cooperation with the patient so as to alleviate and reduce stress he is experiencing.

Patient support groups seem to be a good example of seeking new ways to cope with stress in the process of recovery after bone marrow transplantation. Such a group of patients who had bone marrow transplant from a few months up to 18 years earlier confirms their belief that they had made the right decision about this life-saving modern treatment method, but that their recovery depends on their individual efforts aimed at restoration of functional health, i.e. being a person actively engaged in various spheres of life.

The presented research findings concerning bone marrow transplantation patients seem to have both theoretical and practical importance. They make a substantial contribution to psychology of health by showing multiple determinants and psychological mechanisms of functional health created by the patient himself in relationship with his social environment.

\section{Conclusions}

1. Leukemia patients' health after bone marrow transplantation is associated with their experienced stress level, ways of coping with stress, and personal resources.

2. The study participants' subjective health (mean of selfrated health and sense of calmness scores) depends on their experienced stress level - the higher stress, the lower subjective health, and vice versa.

3. Stress predictors include:

* anxious personality - more often seen in women; and two factors fulfilling a positive function of defense against stress: * the strategy of coping by diverting attention, and $*$ sense of meaningfulness.
4. In blood cancer patients after bone marrow transplantation stress has a regulatory function in the process of recovery:

* high stress levels signal disturbed balance, i.e. a health-threatening condition,

* an optimal stress level is an indicator that the system is at equilibrium, or an indicator of good health.

5. Subjective health predictors of leukemia patients are: objective health, level of stress, by the patient's sense of meaningfulness and focusing on negative emotions

6. According to the $\mathrm{FMH}$, in health promotion the following goals should be aimed at:

* stress level optimization through creative coping,

* enhancement of the patient's personal and social resources,

* evoking and maintaining positive emotions.

\section{References}

Akaho, R., Sasaki, T., Mori, S.L., Akiyama, H., Yoshino, M., Hagiya, K., Nakagome, K., Sakamaki, H. (2003). Psychological factors and survival after bone marrow transplantation in patients with leukemia. Psychiatry and Clinical Neurosciences, 57, 91-96.

Aleksandrowicz, J., Ćwiklicka, A., Płużek, Z. (1971). Niektóre cechy osobowości chorych na różne typy białaczek [Some personality traits in patients with various types of leukemia]. Pol. Tyg. Lek., $26,426-428$.

Antonovsky, A. (1979). Health, Stress and Coping. San Francisco: JosseyBass.

Baltrusch, H.J.F. (1975). Ergebnisse Klinisch-Psychosomatischer Krebsforschung, Psychosom. Med., 5, 175-208.

Blicharski, J., Kwiatkowski, A., Pochopień, A. i Wolska, T. (1983). Ocena skuteczności leczenia i przeżywalności chorych z ostrymi białaczkami w latach 1970-1979. [Evaluation of treatment effectiveness and survival rate in patients with acute leukemia in the years 1970-1979]. Unpublished report, Archives of the $\mathrm{He}$ matology Chair and Clinic, Collegum Medicum, Jagiellonian University.

Endler, N.S., Parker, J.D.A. (1994), Assessment of multidimensional coping: Task emotion and avoidance strategies, Psychological Assessment, 6, 50-60.

Heszen-Niejodek, I. (1996). Stres i radzenie sobie - główne kontrowersje [Stress and coping-major controversies]. In: I. Heszen-Niejodek \& Z. Ratajczak (Eds.) Człowiek w sytacji stresu [Man in the situation of stress. Theoretical and methodological problems] (pp. 12-43). Katowice: Silesian University Press.

Heszen, I. (2013). Psychologia stresu [The Psychology of Stress]. Warszawa: Wydawnictwo PWN.

Heszen, I., Sęk, H. (2007). Psychologia zdrowia [Health Psychology]. Warszawa: Wydawnictwo PWN.

Hobfoll, S.E. (1989). Conservation of resources. A new attempt at conceptualizing stress. American Psychologist 3, 513-524.

Hołowiecki, J. (2006). Przeszczepianie szpiku i komórek krwiotwórczych z krwi obwodowej w nowotworach [Bone marrow and hematopoietic stem cell transplantation in neoplasms]. In: M. Krzakowski (Ed.) Onkologia kliniczna, [Clinical oncology], Warszawa: Wydawnictwo Medyczne BORGIS.

Jabłoński, M. (2004). Zaburzenia depresyjne a przebieg ostrej choroby białaczkowej [Depressive disorders and the course of acute leukemia]. Unpublished doctoral thesis, Library of the Hematology Chair and Clinic, Collegum Medicum, Jagiellonian University.

Jakitowicz, K., Piekarska, A. (2014). Psychological factors crucial in the process of hematopoietic stem cell transplantation. Psychoonkologia, 1, 1-7.

Janicki, K. (2001). Hematologia [Hematology], Warszawa: Wydawnictwo Lekarskie PZWL.

Kępiński, A. (1977). Lęk [Anxiety], Warszawa: PZWL. 
Kübler-Ross, E. (1972). Interviews mit Sterbenden. Stuttgart-Berlin Kreuz-Verlag.

Lazarus, R.S. (1999). Stress and Emotion. A new Synthesis. New York: Springer.

Lazarus, R.S., Folkman, S. (1984). Stress, appraisal and coping. New York, Springer.

Lebiedowicz, H., Skotnicki, A.B. (2005). Wykorzystanie koncepcji fenomenologiczno-poznawczych w pracy klinicznej z pacjentam $\mathrm{z}$ chorobą nowotworową krwi. Doświadczenia własne [Application of phenomenological-cognitive theories in clinical work with leukemia patients. From the author's own experience]. Psychoterapia, 1(132), 57-65.

Łosiak, W. (2007). Natura stresu. Spojrzenie z perspektywy ewolucyjnej [The nature of stress. Seen from the evolutionary perspective]. Kraków: Jagiellonian University Press.

Maruszewski, T. (2002). Psychologia poznania [Psychology of cognition]. Gdańsk: Wydawnictwo GWP.

Miller, S.M., Magnan, Ch.E. (1983). Interacting effects of information and coping style in adopting to gynecologic stress. Journal of Personality and Social Psychology, 45, 223-236.

Molassiotis, A. (1997). A conceptual model of adaptation to illness and quality of life for cancer patients treated with bone marrow transplants, Journal of Advanced Nursing, 26, 572-579.

Nęcka, E. (1994). TroP... Twórcze rozwiazywanie problemów [TroP.. Creative problem solving]. Kraków: Oficyna Wydawnicza IMPULS

Obuchowski, K. (1966). Psychologia dążen ludzkich [The psychology of human aspirations]. Warszawa: PWN.

Rini, C., Redd, W.H., Austin, J. (2011). Effectiveness of Partner Social Support Predicts Enduring Psychological Distress after Hematopoietic Stem Cell Transplantation, J. Consult Clin Psychol. Feb., 79(1), 64-74.

Rusiewicz, A., Duhamel, K.N. (2008). Psychological distress in long-term survivors of hematopoietic stem cell transplantation, Psychoonkologia, 17(4), 329-37.

Schulz-Kindermann, F., Hennings, U., Ramm, G., Zander, A.R. i Hasenbring, M. (2002). The role of biomedical and psychosocial factors for the prediction of painand distress in patients undergoing highdose therapy and BMT/PBSCT. Bone Marrow Transplantation, 29, $341-351$

Selye, H. (1977). Stres okietznany [Stress without distress], Warszawa: Wydawnictwo PZWL.

Skotnicki, A.B., Nowak, W.S. (1998). Podstawy hematologii dla studentów i lekarzy [Essentials of hematology for students and medical practitioners]. Kraków: Wydawnictwo Medycyna Praktyczna.

Solomon, G.F., Amkraut, A.A. (1972). Emotions, stress and immunity. Front. Radiation Ther. Onc., 7, 64-69.

Solomon, G.F. (1985). The Emerging Field of Psychoneuroimmunology Journal of the Institute for the Advancement of Health, 2(1), 6-19.

Solomon, G. (1990). Emocje, odporność i choroba Sol. [Emotions, immunity and illness]. Nowiny Psychologiczne, 1-2, 117-126.

Sosnowski, T. i Wrześniewski, K. (1983). Polska adaptacja inwentarza STAI do badania stanu i cechy leku [Polish adaptation of the STAI for the assessment of state and trait anxiety], Przeglad Psychologiczny, 2, 393-411.

Styczyński, J., Dębski, R., Krenska, A., Czyżewski, K. i Irga, N. (2013). Disease relapse and infectious complications as the main cause of stem cell transplant failure. Postępy Nauk Medycznych, 26(9), 604-608.

Susułowska, M. (1989). Psychologia starzenia się i starości. [Psychology of aging and old age]. Warszawa: Wydawnictwo PWN

Taylor, S.E. (1983). Adjustment to threatening events: A theory of cognitive adaptation. American Psychologist 38(11), 1161-1173.

Witt, M., Szczepański, T. i Dawidowska, M. (red.) (2009). Hematologia molekularna [Molecular hematology]. Poznań: Ośrodek Wydawnictw Naukowych.

Wrona-Polańska, H. (2007). Coping process with Disease and Changes of Self-Concept in Leukemia Patients. Polish Journal of Environ. Stud. Vol. 16, No 5A, 541-545.

Wrona-Polańska, H. (1985). Poziom lęku a czas trwania choroby u chorych na białaczke [Anxiety level and disease duration in leukemia patients]. Polski Tygodnik Lekarski, 40, 1304-1307.

Wrona-Polańska, H. (1991). Self-concept and adjustment to illness in leukemia patients. Polish Psychological Bulletin, 22/3, 169-178.

Wrona-Polańska, H. (1989). Sposoby obrony przed lękiem a obraz samego siebie u chorych na białaczkę [Defenses against anxiety and self-concept in leukemia patients]. Polski Tygodnik Lekarski, $44,446-448$.

Wrona-Polańska, H. (2011). Twórcze zmaganie się ze stresem szansa na zdrowie [Creative coping with stress as a chance for health]. Kraków: Jagiellonian University Press.

Wrona-Polańska, H. (2003). Zdrowie jako funkcja twórczego radzenia sobie ze stresem [Health as a function of creative coping with stress]. Kraków: Wydawnictwo Naukowe Akademii Pedagogicznej.

Wrona-Polańska, H., Skotnicki, A.B., Piątkowska-Jakubas, B. (2013). Zdrowie pacjentów leczonych metodą transplantacji szpiku kostnego a radzenie sobie ze stresem - perspektywa psychologiczna i medyczna [Health of patients undergoing bone marrow transplantation and their coping with stress - from the psychological and medical perspectives]. Przeglad Lekarski, 2013, 70/9, 1-4.

Wrona-Polańska, H. (1984). Zmiany obrazu samego siebie u pacjentów $\mathrm{z}$ chorobą białaczkowa [Changes of self-concept in leukemia patients]. Zeszyty Naukowe UJ, Prace Psychologiczne 1, 137-161.

Wrześniewski, K. (1996). Style i strategie radzenia sobie ze stresem. Problemy pomiaru [Styles and strategies of coping with stress. Problems of assessment]. In: I. Heszen-Niejodek \& Z. Ratajczak (Eds.) Czlowiek w sytuacji stresu. Problemy teoretyczne i metodologiczne [Man in the situation of stress. Theoretical and methodological problems], (pp. 44-64). Katowice: Silesian University Press.

Wrześniewski, K. (2004). Interakcyjny model radzenia sobie ze stresem po zawale serca [Interactive model of coping with stress after myocardial infarction]. In: K. Wrześniewski \& D. Włodarczyk (Eds.) Choroba niedokrwienna serca. [Ischemic heart disease]. Gdańsk: GWP.

Zajonc, R.B., Marphy, S.T., Inglehart, M. (1989). Feeling and facial efference: Implications of the vascular theory of emotion. Psychological Review, 96, 395-416.

Zespół Kliniki Hematologii Szpitala Uniwersyteckiego w Krakowie [Therapeutic team of the Hematology Clinic, University Hospital in Cracow] (Eds.) (2015). Krakowski Ośrodek Hematologiczny w 65-lecie istnienia [The Hematology Center in Cracow - 65-year anniversary]. Kraków: Wydawnictwo PROMO. 